\title{
Gastrin Measurement
}

National Cancer Institute

\section{Source}

National Cancer Institute. Gastrin Measurement. NCI Thesaurus. Code C74858.

The determination of the amount of gastrin hormone present in a sample. 